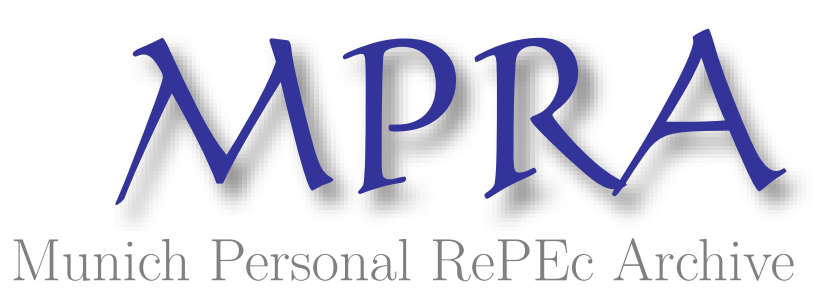

\title{
On The Mechanisms of Achieving Fiscal (Un)Sustainability - The Case of Poland
}

Mackiewicz, Michał and Krajewski, Piotr

March 2007

Online at https://mpra.ub.uni-muenchen.de/16035/

MPRA Paper No. 16035, posted 05 Jul 2009 19:05 UTC 
On The Mechanisms of Achieving Fiscal (Un)Sustainability - The Case of Poland ${ }^{1}$

Michat Mackiewicr?

Piotr Krajewski $i^{3}$

\begin{abstract}
Aim of this paper is to assess empirically the sustainability of budgetary policy in Poland in Years 1992-2005. Our results show that structural surplus did not respond in a way that would stabilize the level of public debt, thus not fulfilling the condition of sustainability. It also showed asymmetric behaviour of revenues and expenditures: while the former tended to adjust to the level of debt in a stabilizing manner, the latter moved independently from debt, while also in a non-stationary way, which made fiscal policy unsustainable in the long run. Fiscal institutions were unable to respond in a debt- stabilizing manner to two large negative budgetary shocks: structural reforms of the public sector, and joining the EU. This makes them unlikely to respond to the future fiscal shocks, and suggests that fiscal institutions in Poland lack the ability to run sustainable fiscal policy.

JEL classification: E60, E63; keywords: fiscal sustainability, fiscal institutions; this version: March 2007
\end{abstract}

\footnotetext{
1 This research was supported by a grant from the CERGE-EI Foundation under a program of the Global Development Network. All opinions expressed are those of the author(s) and have not been endorsed by CERGEEI or the GDN.

${ }^{2}$ Institute of Economics, University of Lodz; corresponding author; mackiewicæ@uni.lod»pl

${ }^{3}$ Institute of Economics, University of Lodz.
} 


\section{Introduction}

Numerous studies in the recent years, both theoretical and empirical, dealt with fiscal sustainability. Sustainability of the public finances has been increasingly considered one of the central characteristics of the economies, that influences both the ability to conduct effective countercyclical fiscal policy, and the central bank's ability to conduct effectively independent monetary policy. The dominant strand of literature (seminal examples are Hamilton and Flavin 1986, Trehan and Walsh 1988; for survey see Bohn 2005) analyzes empirically the behaviour of the fiscal authorities, assessing their sustainability by means of time series techniques, mainly testing integration and cointegration properties of such key fiscal variables as debt and deficit. The existing studies focus mainly on the developed countries, while there are only few that deal with the developing and post-transition economies. Probably the main reason for undersupply of analyses that deal with less-developed economies is poor availability of long, comparable time series in the latter case, which does not allow to achieve sufficient power of the commonly used unit root tests.

Simultaneously, the issue of fiscal sustainability in the new members of the European Union ${ }^{4}$ is now gaining importance, since these countries are expected to join the Economic and Monetary Union, in which member states' fiscal sustainability is considered a precondition for independency of the European Central Bank. Among this group, Czech Republic, Hungary and Poland have already undergone periods of fiscal crises, characterized by high deficits and rapid debt growth, thus raising doubts about their ability to conduct fiscal policies in a sustainable way. The main objective of this paper is to empirically assess the sustainability of fiscal policy in Poland, the largest of the new EU member states. The paper draws largely on the literature on the empirical testing of sustainability. Using the methodology developed by Bohn $(1998,2005)$ it shows that fiscal institutions in Poland lack the ability to react to fiscal shocks in a debtstabilizing manner. We show that while revenues behave in a debt-stabilizing manner, the nonresponsive and non-stationary behaviour of primary expenditures undermines the long-run sustainability of fiscal policy. However, short time series available may raise serious doubts about the power of the respective statistical tests, thus negatively influencing the conclusiveness of the analysis. The statistical results are hence complemented by the analysis of two cases of large fiscal shocks: structural reforms of the public sector undertaken in year 1999, and joining the EU in

\footnotetext{
${ }^{4}$ I.e. countries that joined the EU in year 2004 or later.
} 
2004. It shows that these two cases were largely responsible for the lack of debt-stabilizing behaviour.

Our study extends the existing knowledge in three main aspects. To our knowledge, this is a first study to empirically assess sustainability of public finances in a post-transition country, using theoretically-founded time-series tests. The earlier attempts with similar focus were by Budina and van Wijnbergen (1997), for the group of Central and Eastern European countries, while few examples of analyses with focus on single countries, more similar to our study, are Radulescu (2003) for Romania and Krejdl (2006) for Czech Republic. However, these authors relied mainly on descriptive indicators, such as cyclically-adjusted budget balance, as a measure of fiscal stance. In contrast, we follow the theoretical considerations that give lesser weight to the level of surplus, while stress the importance of the behaviour of surplus, described by the appropriate fiscal rules or fiscal reaction functions. Secondly, we emphasize the role of institutions in achieving sustainability and explicitly test for the impact on large institutional change that took place in the late nineties on the sustainability of public finances.

In the first section we review the concepts of sustainability that are present in the literature. The second section discusses an issue that has drawn little attention in the existing studies, namely which entity can be characterized by fiscal (un)sustainability. Section three briefly describes the methodology of empirical analysis. Sections four and five present the empirical assessment of ability of fiscal institutions to deliver sustainability. In section six we discuss in more detail the effects of fiscal shocks that influenced budgetary outcomes since late nineties. The last section concludes.

\section{Fiscal Sustainability - Theoretical Issues}

According to the dominating concept, fiscal policy is sustainable if it fulfils the Intertemporal Budget Constraint (IBC). The IBC can be derived from the standard budget identity (the first use of this partial equilibrium framework may be attributed to Domar 1944):

$$
b_{t}=\left(1+r_{t}\right) b_{t-1}+\left(g_{t}-h_{t}\right)
$$

where $b_{t}$ is the stock of debt at the end of the period, $g_{t}$ are public expenditures exclusive of interest on public debt, and $h_{t}$ are public revenues. The definition of $r_{t}$ depends on how the other variables are defined. If they are in nominal terms, $r_{t}$ is nominal interest rate. If they are expressed in real terms, $r_{t}$ is real interest rate, while if other variables are expressed as per cent of GDP, $r_{t}$ equals $\left[\left(1+i_{t}\right) /\left(1+\gamma_{t}\right)-1\right]$, where $i_{t}$ is nominal (real) interest rate and $\gamma_{t}$ is the nominal (real) GDP growth rate. Since in a growing economy ratios to GDP provide the fullest information about the variables, we use the latter definition. 
It is useful to reformulate (1) as $b_{t}=(1+r) b_{t-1}+\left(g_{t}^{\prime}-h_{t}\right)$, so that $E\left(r_{t}\right)=r$, while $g_{t}^{\prime}$ is the sum of $g_{t}$ and the transitory component of interest payments $\left(r_{t}+r\right) b_{t-1}$. Iterating the budget identity forward to infinity, one obtains:

$$
b_{t}=\sum_{k=1}^{\infty}\left(h_{t+k}-g_{t+k}^{\prime}\right)(1+r)^{-k}+\lim _{k \rightarrow \infty} b_{t+k}(1+r)^{-k-1}
$$

The intertemporal budget balance holds if and only if sum of discounted primary surpluses equals present debt, i.e. if:

$$
\lim _{k \rightarrow \infty} b_{t+k}(1+r)^{-k-1}=0 .
$$

The Intertemporal Budget Constraint (3) (technically, a transversality condition) means that in the long run debt cannot grow at a rate equal to, or higher than, the interest rate. In the simplest interpretation this means that in a dynamically efficient economy achieving a positive primary surplus on average is a necessary and sufficient condition for achieving sustainability.

However, such an interpretation raises a number of issues. Barro (1989) and Kremers (1989) point at a controversial case when debt-to-GDP ratio grows indefinitely, while at a positive rate $r_{1}$, such that $r_{1}<r$. Though such a scenario fulfils IBC, interest payments as a share of GDP would grow permanently with rate $r_{1}$. Since for sustainability to hold it is necessary to achieve positive average primary surplus, this implies either falling primary expenditures, or growing revenues (both expressed as their ratios to GDP). Under the well-behaving utility functions of representative households, beyond some debt level $\bar{b}$ it would be optimal for the government to default on its debt rather then to follow the policy of debt growth, which increases tax rates and/or squeezes out the primary expenditures. We, hence, limit our definition of sustainability to cases when the growth of debt as a share of GDP remains bounded below $\bar{b}$. This is the Bounded Debt Constraint (BDC), which, being more stringent than IBC, seems to be more practically relevant. It should be noted that importance of upper bound on debt has been recognized in practice and gave birth to such regulations as the 60\% GDP debt limit enshrined in the Maastricht treaty and the Stability and Growth Pact, or the constitutional limit on the public debt in Poland.

There are two ways to make this requirement operational as a sustainability test, one of which is simply setting a limit above which we consider debt as unsustainable. An obvious problem of this approach is that there is no widely accepted method of assessing which debt level is sustainable. Another possibility is testing the unit root properties of public debt - fiscal policy is sustainable if debt-to-GDP ratio is stationary (is $\mathrm{I}(0)$ ). One should note that debt being $\mathrm{I}(0)$ is neither necessary nor sufficient condition for BDC to hold - debt may be nonstationary, while fulfilling the BDC, if it asymptotically grows towards $b_{1}<\bar{b}$. Another possibility is that debt can be $I(0)$, while 
remaining so close to $\overline{\mathrm{b}}$ that probability of debt exceeding it becomes non-negligible. However, since both cases seem to be of limited practical relevance, in the literature testing whether time series of public debt to GDP ratio is stationary is often used as a good approximation of testing for BDC. Hence, assessing fiscal sustainability means testing for significance of (positive) parameter $\varrho$ in equation:

$$
\mathrm{s}_{\mathrm{t}}^{\prime}=\alpha_{0}+\varrho \mathrm{b}_{\mathrm{t}-1}+\varepsilon_{\mathrm{t}}
$$

where $s_{t}^{\prime}$ denotes total fiscal surplus. A second major problem with testing for empirical validity of the Intertemporal Budget Constraint (3) is that it defines only a very limited concept of sustainability, by Bohn (1998) named an ad hoc sustainability. Intuitively, Bohn's argumentation is that ad hoc sustainability takes the discount rate as given, and hence ignores the optimizing behaviour of lenders in the presence of uncertainty. When the latter is taken in to account, one may show that some policies that do not satisfy IBC in the form (3) are, nevertheless, sustainable. To address these issues, Bohn proposes an alternative concept of model-based sustainability, that derives government's borrowing constraint from the utility-maximizing decisions of lenders. He proves that this kind of sustainability can be also tested using equation (4), while total surplus on the lhs. should be replaced by primary surplus. While positive and statistically significant $\varrho$ is a sufficient condition, it is not a necessary condition, since model-based sustainability can be also achieved if $\varrho$ takes positive values only for high levels of debt (for details see Bohn 2005).

Using (4) for directs tests has, however, its pitfalls. If primary deficit and debt are not cointegrated (which also implies non-stationarity), omission of other determinants of surplus may result in inconsistency of estimator of the adjustment parameter $\varrho$. Hence, it is advisable to enhance equation (4) through adding other regressors on the right hand side that allow to control for factors that exert transitory impact on primary surplus and, hence, do not change the longrun behaviour of the public debt. Then equation takes the form:

$$
\mathrm{s}_{\mathrm{t}}=\alpha_{0}+\mathrm{eb}_{\mathrm{t}-1}+\alpha^{\prime} \mathbf{x}_{\mathrm{t}}+\varepsilon_{\mathrm{t}}
$$

where $s_{t}$ is primary surplus, $\mathbf{x}_{t}$ is a vector of determinants that exert transitory impact on surplus, and $\varepsilon_{\mathrm{t}}$ is a disturbance term. In this paper we use tests of the statistical significance of $\varrho$ in different specifications of (5) as a central method of assessing fiscal sustainability in Poland.

\section{Sustainability of What?}

A problematic issue, while commonly neglected in the existing studies, is what is the entity that is supposed to be (possibly) sustainable. Surprisingly, most authors did not specify clearly what is the agent whose behaviour they were analyzing, writing vaguely about "fiscal policy". As we will 
show, posing such a question raises a number of new issues related to the conventional concept of sustainability.

Beginning from the simplest possibility, an entity under consideration can be the budgetary outcome in a chosen year. The main problem is that fiscal policy cannot be assessed sustainable or not, since, except for some extreme cases, literally any fiscal outcome may be offset in the following years. Only at the verge of fiscal crisis can it be assessed as unsustainable, when it leads directly to default. However, as most of the time countries are not in crises, such cases are of little practical importance.

Another possibility is the an entity of interest is a single government (defined, for example, as the cabinet led by the same prime minister). Since it usually survives several years, its actions undertaken within this period may be unsustainable, if they lead to an excessive build-up of debt and possibility of insolvency. A single government typically represents a stable set of preferences, hence its actions may be described by a reaction function with constant parameters. If this would be the case, a typical title of an empirical paper would be "Assessment of fiscal sustainability of government $\mathrm{X}$ in country Y". Reasons for this not being the case are possibly twofold, of both practical and theoretical nature. The practical one is that even in stable democracies the average government tenure is too short to make any assessment empirically feasible. A short time span raises also a theoretical problem, similar to the case of a single year. Since sustainability is necessarily a concept that refers to the long-run, for any assessment of sustainability it is at least equally important what happens during the term, as what happens after the present government resigns.

Hence, in order to make sense of sustainability, one needs to look at a longer-lived entity. A flourishing strand of literature suggest that the fiscal actions of the governments are under constant, major influence of the existing institutional setup. While driven by the preferences of the principals they represent, governments operate in institutional environments that largely limit their ability to freely use fiscal policy in a discretionary manner. Empirical studies confirm that characteristics such as fiscal institutions, elections and polarisation of preferences tend to have a strong impact on the way fiscal policy is being conducted (see Drazen 2000 and Woo 2006 for reviews of developments in this field). One may expect that this influence includes also the way the governments deal with sustainability. Hence, the aspects of behaviour that are vital to sustainability do not vary then with every change of government, but rather largely remain the same, if the key fiscal institutions remain unchanged. This makes institutions a natural candidate for entity fiscal sustainability of which can be assessed. Since significant changes of institutions occur infrequently, we can expect that the existing institutions shall remain in place for a period 
that is sufficiently long to be indistinguishable from "infinity". This solves another problem linked to using either a year or a government the entity under examination - since sustainability is essentially a long-run concept, the entity should also be infinitely-lived. It is crucial to note, however, that conjecture of institutions being fiscally sustainable makes sense only as long as we can assume that the existing institutions remain in place for a long time ("infinitely"). Hence, verdict "(un)sustainable" is conditional on the assumption that the existing set of fiscal institutions remains in place for a foreseeable future.

Some available studies go even further, assessing fiscal sustainability of a country itself, rather than of some entities within a country. Examples are Bohn 2005 and Marinheiro 2006, who perform their analyses basing on time series with time span close to 100 years. Within such period a very limited set of entities related to fiscal policy remain stable, one of which is a country itself, hence using such a long time span implies referring to a country as entity the sustainability of which is assessed. In our opinion it is, however, doubtful, whether fiscal actions undertaken 100 or 80 years ago contain useful information about how fiscal policy will react to changing states of the world within the next 20 or 30 years. Knowledge about the reaction functions that were in place at that time, under very different set of social preferences with respect to the role of state, can say little about behaviour of public debt within the future period that is vital to sustainability. In this case, a country per se does not fulfil the requirement of constancy, both in the past and into the future, hence it is impossible to meaningfully assess its prospects in terms of sustainability.

Our objective in this paper is to assess sustainability of fiscal institutions in Poland in years 19912005. It is reasonable to expect that fiscal institutions during this period remained largely in place. We test, however, empirically for the possibility that institutional setup changed considerably when a new constitution that contains references to fiscal variables was introduced. Our approach is to first analyze sustainability within the whole period, and then try to account for possible institutional changes using several criteria. The next section presents the used methods and results of empirical analysis.

\section{Empirical Methods And The Main Results}

For our study we used fiscal data from the Reports on Budget Execution, provided by the Ministry of Finance. However, due to a number of structural changes that took place in the public sector within the period under consideration, the raw data are incomparable across years. In order to achieve comparability, the data were adjusted for the effects of shifts of revenues and expenditures between different budgetary sections, as well as between central budget and other 
public entities such as extrabudgetary funds and local governments. Information on these shifts, reported in details in Appendix A, was obtained through a detailed analysis of the Reports on Budget Execution.

Following Bohn (1998, 2005), our central method of assessing fiscal sustainability of Polish institutions is to estimate parameters of the equation (4). A standard specification is:

$$
\mathrm{s}_{\mathrm{t}}=\alpha_{0}+\mathrm{eb}_{\mathrm{t}-1}+\alpha_{1} \widetilde{\mathrm{g}}_{\mathrm{t}}+\alpha_{2} \widetilde{\mathrm{y}}_{\mathrm{t}}+\varepsilon_{\mathrm{t}},
$$

where $\widetilde{g}_{t}$ and $\widetilde{y}_{t}$ denote, respectively, transitory component of government outlays, and output gap. For the purpose of our study we modified this equation in three main ways. Firstly, we set $\alpha_{2}=0$ and used cyclically-adjusted values instead, which allowed us to allow for varying elasticities with respect to output gap, and saved one degree of freedom. ${ }^{5}$ Secondly, since the cyclical component is present not only in primary surplus, but (cumulatively) in debt as well, we adjusted debt for the cumulative difference between actual and structural surplus. Finally, we extended the definition of $\widetilde{g}_{t}$ included on the right hand side.

Typically, $\widetilde{g}_{\mathrm{t}}$ is calculated as a deviation of actual outlays from trend, as obtained from HodrickPrescott filter. Such an approach raises twofold concerns. Bohn originally included $\widetilde{g}_{t}$ in his studies concerning the American economy mainly in order to control for peaks in military spending that occurred during wars and were clearly outliers. Following the same procedure in our short sample would actually mean calculating deviations from a linear trend. It is, however, not plausible to believe that any spending that lies above or below such a trend is necessarily of a transitory nature. In our study we allowed for more flexible trend, calculating transitory component of expenditures as a deviation from 3-years moving average. Secondly, while in principle the governments follow the tax smoothing strategy, hence keeping the tax rates roughly constant, it is unrealistic to assume that the revenue side of the budget does not contain transitory components (often called one-off revenues). Hence, we also included the deviation of revenues from their 3-years moving average, as a measure of transitory component on the revenue side. Finally, we estimated equation of the form:

$$
\overline{\mathrm{s}}_{\mathrm{t}}=\alpha_{0}+\varrho \overline{\mathrm{b}}_{\mathrm{t}-1}+\alpha_{1} \widetilde{\mathrm{s}}_{\mathrm{t}}+\varepsilon_{\mathrm{t}}
$$

where dashes denote cyclically-adjusted levels of the respective variables, and $\widetilde{s}_{t}$ includes transitory components of surplus (equal the difference between transitory components of

\footnotetext{
${ }^{5}$ Appendix A describes the methods of calculating the cyclically-adjusted figures of expenditure, income, deficit and debt.
} 
revenues and expenditures). In order to account for possible partial adjustment scheme in taking the discretionary policy decisions, we allowed the error term $\varepsilon$ to follow an autoregressive process of order 1.

Results of estimation are presented in column (1) of Table 3 in Appendix C. The point estimate of the key parameter $\varrho$ is positive and equals 0.062 , which may suggest that existing institutions forced an increase in primary surplus as a reaction to the growth of debt. However, the p-value calculated from the $\mathrm{t}$ distribution is as high as 0.096 , hence the robustness of the error-correction mechanism is questionable. This is even more so since one can argue that, due to possible nearunit root behaviour, t-statistics should be compared against Dickey-Fuller rather than $t$ distribution. Further inspection of statistics uncovers even more severe problem. The point estimate of autoregression parameter of the disturbance term close to unity points at a near-unit root behaviour of the disturbance term. From a statistical point of view this may suggest that either primary surplus or debt are integrated, while they do not cointegrate. Since short time span of the sample suggests being careful about conclusions concerning unit-root properties, we prefer a weaker interpretation that fiscal surplus is to a large extent influenced by factors that do not respond to the level of debt in a way that would ensure sustainability.

Following our arguments concerning impact of institutional changes on sustainability, it is crucial to identify any possible shifts of fiscal institutions that took place within the analyzed period. Indeed, one such episode was the new constitution introduced in year 1997, that imposed 60\% ceiling on the ratio of public debt to GDP. Together with the new Act on Public Finances, it might have significantly changed the process of fiscal policymaking in Poland. The Act on Public Finances supplemented constitution with the emergency procedures that are supposed to brake the growth of debt through increasingly severe constraints on deficit, when public debt reaches the thresholds of 50, 55 and $60 \%$ of GDP. Since such a change might have considerably modified fiscal institutions in Poland, we ran the regression similar to (7), with dummy PCON (that takes value of 1 from year 1998 on, and 0 before that date) introduced both as a constant term and as interaction variable with public debt:

$$
\overline{\mathrm{s}}_{\mathrm{t}}=\alpha_{0}+\alpha_{3} \mathrm{PCON}+\varrho_{1} \overline{\mathrm{b}}_{\mathrm{t}-1}+\varrho_{2} \mathrm{PCON} \cdot \overline{\mathrm{b}}_{\mathrm{t}-1}+\alpha_{1} \widetilde{\mathrm{s}}_{\mathrm{t}}+\varepsilon_{\mathrm{t}},
$$

Results of the estimation are presented in column (2) of Table 3. While the estimate for $\varrho_{2}$ is not significantly different from 0 at the conventional $5 \%$ level, its $\mathrm{p}$-value is close to this threshold and equals 0.056. Given the low power of t-test in a short sample, this result does not give a definite answer as to whether fiscal institutions changed significantly after the new constitution became effective. Alternatively, we also tested the hypothesis that institutional change took place gradually within the given period, through inclusion of time trend both separately and as an 
interaction with lagged debt. The results (not reported here) do not point at presence of any such effect. Given the described results, while not rejecting, we treat with caution notion that fiscal institutions in Poland remained constant within the period under consideration.

\section{$4 \quad$ Fiscal adjustments - decomposition}

In order to examine mechanisms behind the observed unsustainability, it is worthwhile to see, whether the observed adjustment of primary deficit as a reaction to changes of debt results primarily from the expenditure or the revenue side of the budget. To test the corresponding hypotheses, we estimated parameters of equation of a general form

$$
\bar{x}_{t}=\alpha_{0}+\varrho_{x} \bar{b}_{t-1}+\alpha_{1} \widetilde{x}_{t}+\varepsilon_{t}
$$

where $\mathrm{x}_{\mathrm{t}}$ denote the fiscal variable of interest, which in this case were primary expenditures and revenues, respectively. The results, presented in columns (3) and (4) of Table 3, show that virtually all the fiscal adjustment in response to changes in debt came from the revenue side. With reaction parameter equal 0.15 and high t-statistics (suggesting significance both compared against $\mathrm{t}$ and Dickey-Fuller distributions), the revenue side of the budget was a paramount tool to counteract the debt growth. In contrast, the reaction parameter for expenditures is low and insignificantly different from 0 .

These results suggests that there was a strong asymmetry of fiscal reactions; while revenues were responsive to public debt, expenditures did not provide a useful tool for stabilization of debt-toGDP ratio. This result is of crucial importance, if compared to the results of the empirical studies on fiscal consolidations (Alesina et al. 1998). They show that while deficit reductions through cutting expenditures are often successful, consolidations that are based on increases of revenues have much lower probability of a strong and long-lasting effect on deficit. Given the evidence on low quality of revenue-based consolidations, relying by Polish governments mainly on revenues rather than expenditures as a tool to stop the debt growth is a bad signal in terms of sustainability. The use of this tool is, at least in the long run, bounded by numerous factors: international tax competition, the Laffer curve and the political factors that limit increases of the tax rates beyond level accepted by society. Hence, preventing the public debt growth may not rely solely on the revenue side; if it does, it clearly jeopardizes fiscal sustainability.

In order to further test confirm existence of the described patterns, we ran a number of Granger causality tests for the time series of public debt, revenues and primary expenditures. The results (presented in Table 4) confirmed our earlier presumptions. The level of public expenditures does Granger-cause (at 5\% significance level) both level of debt and level of revenues. While debt Granger-causes revenues, the latter do not Granger-cause any of two other variables. This 
suggests that while expenditures are sensitive to neither debt nor revenues, debt is sensitive to expenditures only, and revenues react to both expenditures and debt. Keeping in mind that Granger causality is clearly not equivalent to causality per se, our results suggest a specific sequence of fiscal policymaking. The expenditures move as first and follow their own path, without any concern for sustainability. This causes the reaction of revenues that adjust public debt in such a way that a feedback mechanism that ensures sustainability is preserved.

Since the Granger causality test may be sensitive to the violation of stationarity assumptions, we repeated the same tests on first differences. We obtained similar results concerning relationship between expenditures and the two other variables. While (the first difference of) expenditures do Granger-cause both debt and revenues, while the opposite does not hold. The only difference from the results for levels is the relationship between debt and revenues: tests did not confirm debt to Granger-cause revenues, while the opposite was true. Summarizing, the Granger causality test confirmed the lack of the error-correction mechanism on the expenditure side, while the results as to the role of revenues were less clear.

The way to further explore the way institutions provide sustainability is to check, which of the main budget components is mainly responsible for the observed pattern of reactions to the public debt. We disaggregated thus the expenditure side into the four main components - social expenditures (state pension schemes, disability benefits and social aid), quasi-social ${ }^{6}$ expenditures (health and education), outlays on the primary functions of state (security, justice and administration), and others. We estimated parameters of equation (9), using as fiscal variable $\mathrm{x}$ each of the four components of expenditures. Our results (presented in Table 5) show that none of the expenditures responds to public debt in the expected way. While the reaction of social expenditures is statistically insignificantly different from 0 , while having the proper sign, expenditures in the other three categories tend to grow, as debt grows. This surprising result may be a consequence of two factors acting jointly: the stock-flow relationship between expenditures and debt, coupled with high autocorrelation of the latter variable. The long periods of high and persistent expenditures cause debt to grow, resulting in periods when both variables reach high levels. While this result is difficult to reconcile with standard sustainability conditions, it confirms our earlier observations that expenditure do not adjust to the debt level in the correct way, thus putting sustainability at risk, if revenues fail to adjust sufficiently.

On the revenue side, we ran the regressions separately for direct taxes, indirect taxes, and other sources. Our preliminary results (not reported here) did not show a significant impact of neither

\footnotetext{
${ }^{6}$ The reason we call them quasi-social expenditures is explained in the next section.
} 
public sector reforms nor the EU enlargement. They also indicated a presence of time trends in revenues from indirect taxation and other sources. An upward trend in indirect taxes reflects mainly the effects of the EU harmonisation process, while downward trend in revenues from other sources result mainly from the decreasing role of revenues from customs duties. A way to control for this shift from other sources of income towards indirect taxes is to use these sources of revenues jointly as the dependent variable.

The results of estimations (see columns (5) through (8) in Table 5) suggest that all sources of revenues provided stabilizing effect on the level of public debt, while the size of effect was not equally strong. They give a convenient decomposition of the reaction parameter $\varrho$ for the total revenues, equal 0.13. According to the estimates, the debt stabilization relied to the largest extent on the adjustment of direct taxation; the respective $\varrho$ parameter amounted to 0.05 . In the case of indirect taxes and other sources $\varrho$ was, respectively, 0.033 and 0.026 . For the latter two sources of revenues combined the reaction parameter amounted to 0.07 . All the parameters were statistically significant at conventional levels.

\section{Long-run Stability of Debt, Expenditures and Revenues}

The evidence presented so far suggests presence of a long-run stability of the system of revenues, expenditures and debt. Reactions of revenues stabilized public debt, which, in line with the key criterion as derived by Bohn (1998), provides the long-run sustainability. This, however, does not mean that the properties of expenditures can be disregarded. One can think of an extreme case when expenditures as a share of GDP grow along a trend. Even if revenues adjust strongly enough to prevent public debt (also as a share of GDP) from explosion, such a process would lead in the long run to tax rates exceeding socially acceptable levels, and as a consequence, to either insolvency or necessity of an abrupt shift in the institutional setup. Hence, particularly the mean-reversion properties of expenditures are of paramount importance for assessing sustainability of Polish fiscal institutions.

So far, our results indicated that expenditures did not react to public debt in a stabilizing manner. However, given the stabilizing effect of revenues, for sustainability it would be sufficient that expenditures follow some error correction mechanism that makes them fluctuate around a stationary level. A way to assess the mean-reversion properties of expenditures is to estimate parameters of equation:

$$
\Delta \bar{g}_{t}=\beta_{0}+\beta_{1} \bar{g}_{t-1}+\beta_{2} \Delta \widetilde{g}_{t}+\varepsilon_{t},
$$

where $\bar{g}_{t}$ denote (cyclically-adjusted) primary expenditures. The estimation results, presented in Table 6, suggest lack of a statistically significant mean-reverting behaviour of primary 
expenditures. Following our main strategy, in order to further explore the mean-reverting behaviour of the expenditure components, we repeated estimating parameters of equation (10), replacing $\Delta \bar{g}_{t}$ on the left hand side with each of the four specified earlier categories of outlays. The results show that none of the types of expenditures responds to the expenditure growth in a stabilizing, statistically significant manner.

The overall picture concerning sustainability that is provided by fiscal institutions in Poland is mixed. Revenues tend to react to growth of public debt in a stabilizing manner, while expenditures are shaped without concern to taming the growth of debt. Since expenditures do not react to public debt, nor even they present a mean-reverting behaviour, the debt-stabilizing reactions of revenues is sufficient to guarantee the existence the upper bound on public debt. Hence, our results suggest so far that fiscal institutions in Poland were unable to shape key fiscal variables in a way that would facilitate achieving sustainability through implementation of corrective actions in response to periods of the debt growth.

\section{On The Two Cases of Large Expenditure Growth}

Our empirical results point at a paramount role of expenditures in shaping fiscal outcomes in Poland. Given the complexity of institutional setup, it is infeasible to directly examine the mechanisms that underlie the single decisions concerning every item of expenditures. However, a good picture can be obtained from the analysis of two large events that have eventually led to large increases of deficits: the reforms implemented in year 1999, and joining the EU in 2004. These two cases provide anecdotal evidence on the mechanisms that would defend public finances against the common pool problem and inability to perform effective fiscal adjustment, extensively described in the literature on political economy of fiscal deficits.

The first of the described shocks came in year 1999, when the rightist, post-anticommunist bloc introduced a set of 4 large reforms of the public sector. The reforms were the key element of the programme of the coalition parties, and were designed to rebuild almost all main functions of state: education, healthcare, administration and social security. According to the dominant rhetoric used by politicians, the main purpose of reforms at that time was not an improvement in fiscal balance, but rather modernizing the way state delivers its services, in order to modernize them and increase effectiveness. An exception was the reform of pension system, the main objective of which was a shift from pay-as-you-go to a partly funded system in order to alleviate future fiscal stress linked with aging of the society. According to the estimates of Krajewski (2001), this reform also created the heaviest fiscal stress, increasing outlays on social security by around $2 \%$ of GDP. Krajewski estimates the total fiscal stress caused by 4 reforms at $1.9 \%$ GDP 
during their peak in year 2002, whilst in the long run the annual cost should stabilize at the level of $1.5 \%$ of GDP.

Another fiscal shock resulted from Poland's joining the European Union, which took place in May 2004. While being advantageous in terms of net flows to the economy as a whole, it caused considerable increase of expenditures. The state budget was obliged to pay contributions to the EU budget and participate in the EU-funded projects, while obtaining little extra financing. Mackiewicz et al. (2003) estimate joining the EU to increase deficit of the central state budget by $1.4 \%$ of GDP in year 2005, the first full year of membership.

Importance of the two shocks for primary surplus and expenditures can be seen on Figure 2 in Appendix C. They account for majority of the deficit growth that took place since year 1999: after having removed their estimated effects, the downward trend that has been present in years 1999-2005 disappears. A way to assess their role in shaping sustainability is to include the respective dummy variables among the regressors in equation (7). We estimated parameters of the following equation:

$$
\bar{s}_{t}=\alpha_{0}+\varrho \bar{b}_{t-1}+\alpha_{1} \widetilde{s}_{t}+\alpha_{2}(\operatorname{PREF}+\operatorname{PEU})+\varepsilon_{t},
$$

where PREF and PEU are dummy variables that take values equal to the estimated effects of both fiscal shocks, as per cent of GDP (results are presented in column (6) of Table 6). The estimated coefficient, equal .79, is statistically significant at conventional levels of significance. it is also slightly lower than unity (however, not in a statistically significant way), which might suggest that both shocks were partly accommodated, either by decrease in other expenditures, or by an increase in revenues. Moreover, adding the dummy variable changed the main statistics obtained from equation (11), in comparison to the ones from equation (7), in two important ways. Firstly, the estimate of parameter $\varrho$ became statistically significant, which suggests presence of the stabilizing effect of the primary surplus on debt. Secondly, autoregression coefficient of the disturbance term is now .35, instead of the earlier .96, which now makes fiscal shocks stationary. Much weaker autocorrelation is also reflected in a considerably higher Durbin-Watson statistics, which grew to 1.6 as compared to the earlier 0.3. These results suggest that many of the described earlier unsustainable behaviour of fiscal variables disappear if the impact of two large fiscal shocks is controlled for.

Naturally, the above results do not indicate that fiscal institutions in Poland tend to make policy more responsive to fiscal debt, or more sustainable. The two fiscal shocks are not transitory by nature. The objective of the reforms that were undertaken in 1999 was to permanently change the public sector, which also means permanently changing the finances of public sector. Entering 
the EU also entails worsening of fiscal balance that is permanent, since in the accession process there are no mechanisms available that would gradually alleviate the associated fiscal burden. The only way to think of the shocks as of a transitory phenomenon is to expect that their effects are offset by an decrease in other expenditures or by an increase in revenues. Estimation results show that this did not take place, hence Polish fiscal institutions can be again viewed as unable to run policies that would react to shocks in a way that could eventually stabilize the public debt.

\section{Conclusions}

The empirical analysis of the behaviour of key fiscal variables suggests a consistent, though negative picture of institutions in Poland that are responsible for running budgetary policy. Our results show that structural surplus did not respond to fiscal shocks in a way that would stabilize the level of public debt, thus not fulfilling the key condition of sustainability. The behaviour of expenditure and revenue side was not symmetric, however. While revenues tend to adjust to the level of debt in a stabilizing manner, expenditures move independently from debt and in a nonstationary way, which makes fiscal policy unsustainable in the long run. This pattern was confirmed by tests of Granger causality that showed that while revenues do adjust to both changes of expenditures and debt, primary expenditures are Granger-independent from both other main fiscal variables. Fiscal institutions in Poland were unable to respond in a debtstabilizing manner to two large negative budgetary shocks: structural reforms of the public sector undertaken in year 1999, and joining the EU in 2004. This makes them unlikely to respond to the future fiscal shocks, and suggests that fiscal institutions lack the ability to run sustainable fiscal policy.

Certainly, the presented analysis is subject to a number of concerns. Firstly, it is unclear whether such a short sample allows one to draw conclusions about sustainability, which is inherently a long-run concept. However, although the short sample makes the analysis rather preliminary, there were no signs of considerable changes in the ability of fiscal institutions in Poland to run fiscal policy that would be responsive to the level of debt. Given this, 13 years of unsuccessful, in terms of deficit and debt, fiscal policy is a period that allows to make first observations concerning the main relationships that shape Polish fiscal policy.

Secondly, the criterion we used may only be sufficient, whilst not necessary. For sustainability to hold it would be sufficient if positive reactions of primary surplus to fiscal debt took place for higher debt levels, possibly higher than those achieved in Poland within the analyzed period. This concern has no clear answer, since the "next year we will start repaying the debt" policy is seemingly always a solution to sustainability problems. However, such fiscal adjustments made 
when debt is high are likely to require also adjustments of the fiscal institutions, which in turn means that the present institutions were not sustainable. Hence, in our view the existing evidence shows that the existing fiscal institutions in Poland are not sustainable, if one rules out as unlikely the possibility that they suddenly start behaving responsively while some high debt level is achieved. 


\section{References}

Alesina A, Perotti R, Tavares J, Obstfeld M, Eichengreen B (1998) The Political Economy of Fiscal Adjustments. Brookings Papers on Economic Activity. 1998(1):197-266

Barro RJ (1979) On the Determination of the Public Debt. Journal of Political Economy 87(5):940-971

Barro RJ (1989) The Ricardian Approach to Budget Deficits. Journal of Economic Perspectives 3(Spring):37-54

Bohn H (1998) The behavior of U.S. public debt and deficits. Quarterly Journal of Economics 113(3):949-963

Bohn H (2005) The sustainability of fiscal policy in the United States. CESifo Working Paper 1446

Bohn H (2006) Are Stationarity and Cointegration Restrictions Really Necessary for the Intertemporal Budget Constraint?. Manuscript

Budina N, van Wijnbergen S (1997) Fiscal Policies in Eastern Europe. Oxford Review of Economic Policy 13(2):47-64

Domar ED (1944) The Burden of the Debt and the National Income. American Economic Review 34:798-827

Drazen A (2000) Political Economy in Macroeconomics. Princeton University Press, Princeton

Hamilton J, Flavin M (1986) On the Limitations of Government Borrowing: A Framework for Empirical Testing. American Economic Review 76:808-819.

Krajewski K (2006) Structural And Cyclical Component of Budget Deficit in Poland [in Polish]. Lodz University Press

Krejdl A (2006) Fiscal Sustainability - Definition, Indicators and Assessment of Czech Public Finance Sustainability. Working Paper of the Czech National Bank 3/2006

Kremers JJM (1989) U.S. Federal Indebtedness and the Conduct of Fiscal Policy. Journal of Monetary Economics 23(March):219-38

Marinheiro CF (2006) The sustainability of Portugese fiscal policy from a historical perspective. Empirica 33:155-179

Krajewski P (2001) Fiscal Implications of Public Sector Reforms And The Maastricht Fiscal Criteria. Gospodarka Narodowa 121(9):72-86 
Mackiewicz M, Malinowska-Misiag E, Misiag W, Niedzielski A, Tomalak M (2003) Financial Consequences of Poland's Joining the European Union. The Gdansk Institute for Market Economics, Warszawa

Neck R, Getzner M (2001) Politico-economic determinants of public debt growth: a case study for Austria. Public Choice 109:243-268

Radulescu DM (2003) An Assessment of Fiscal Sustainability in Romania. Post-Communist Economies 15(2):259-275

Roubini N, Sachs JD (1989) Political and Economic Determinants of Budget Deficits in the Industrial Democracies. European Economic Review 33(6):903-938

Trehan B, Walsh C (1988) Common Trends, The Government Budget Constraint, and Revenue Smoothing. Journal of Economic Dynamics and Control 12:425-444

Woo J (2006) The Political Economy of Fiscal Policy. Public Deficits, Volatility and Growth. Springer-Verlag 


\section{Appendix A. Definitions and adjustments made to the data}

All data on fiscal revenues, expenditures and debt come from Reports on Budget Execution, prepared by Ministry of Finance and approved by the national parliament (Sejm and Senat). However, a number of definitional and structural shifts performed in years 1992-2005 blur the official data and make them incomparable across time. To bring data to comparability we adjusted the officially-reported numbers in the following way:

- In 1999 the healthcare reform established the Special Health Authority (followed later by the National Health Fund) that took over the responsibility for financing healthcare, using the specially assigned share in revenues from PIT. As a consequence, central budget's expenditures on healthcare plunged, which was accompanied by a corresponding drop in budgetary revenues. We adjusted the data for period from 1999 on for the impact of the reform, so that they are comparable with pre-1999 time-series.

- According to the interpretation of budgetary law introduced by Finance Ministry in 2004, a part of transfers to Open Pension Funds may not be included among outlays on social security. However, since OPFs are not part of public finance, such transfers affect sustainability, hence we adjusted data in 2004-2005 for the effect of this budgetary creative accounting.

- A significant source of variation of central budget's revenues from personal and corporate income taxation were changes in local governments' shares. To control for these changes, which are irrelevant to sustainability, we calculated revenues as if local governments' shares were set to 0 .

- Data on tax revenues, outlays on social security and social aid, and deficit were adjusted for the impact of the business cycle. We used the standard "gap plus elasticity" methodology, for which output gap was estimated using the Hodrick-Prescott filter, while the output elasticities of budgetary items were provided by Krajewski (2006). In order to completely remove the cyclical effect from time-series, we also adjusted figures on public debt were also corrected using the data on accumulated cyclical component of budget deficit.

- Public debt was corrected for the accumulated revenues from privatisation. The final data we used express numbers as if privatisation did not take place. Such an adjustment is necessary, since privatisation artificially lowers public debt, i.e. it reduces gross debt, while not affecting the net worth of the public sector, which is more relevant for sustainability. 
Hence, reduction of public debt using proceedings from privatisation has no effect on sustainability. 
Appendix B. Descriptive statistics

Figure 1. Debt $(C B)$, revenues $(C H)$ and primary expenditures $(C G$, as \% of GDP)

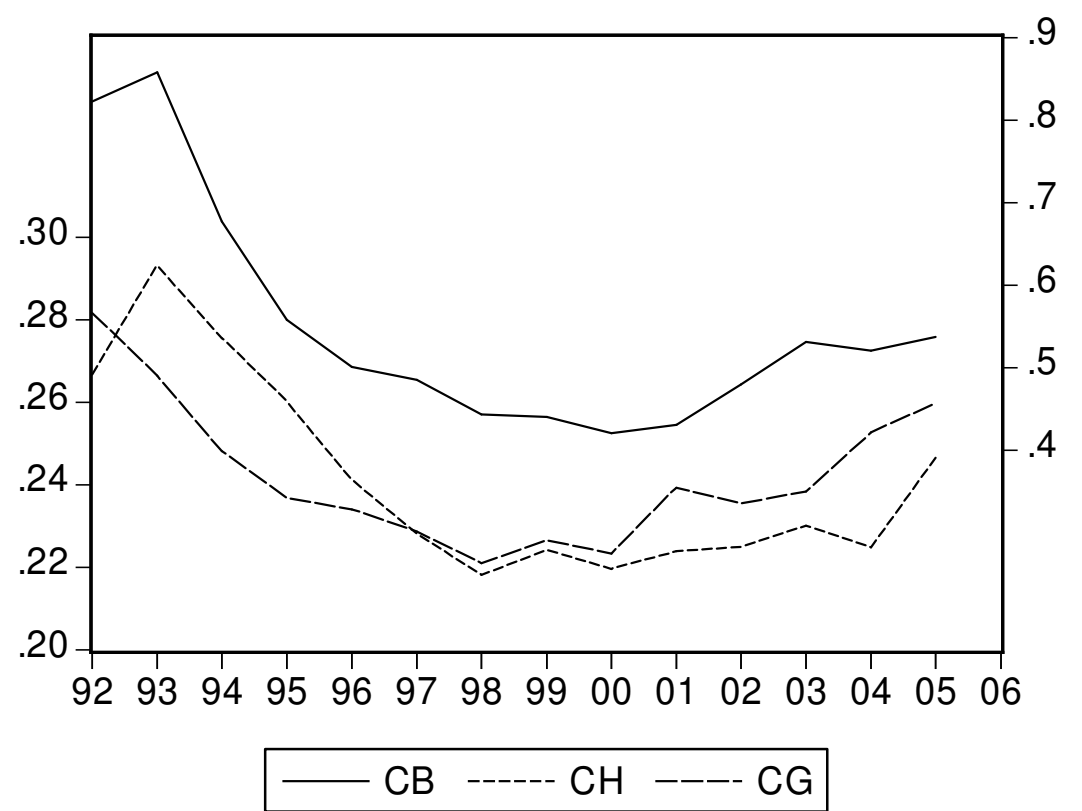

Figure 2. Impact of fiscal shocks (PEU+PREF) on expenditures $(C G)$ and primary surplus (CS, as \% of GDP)
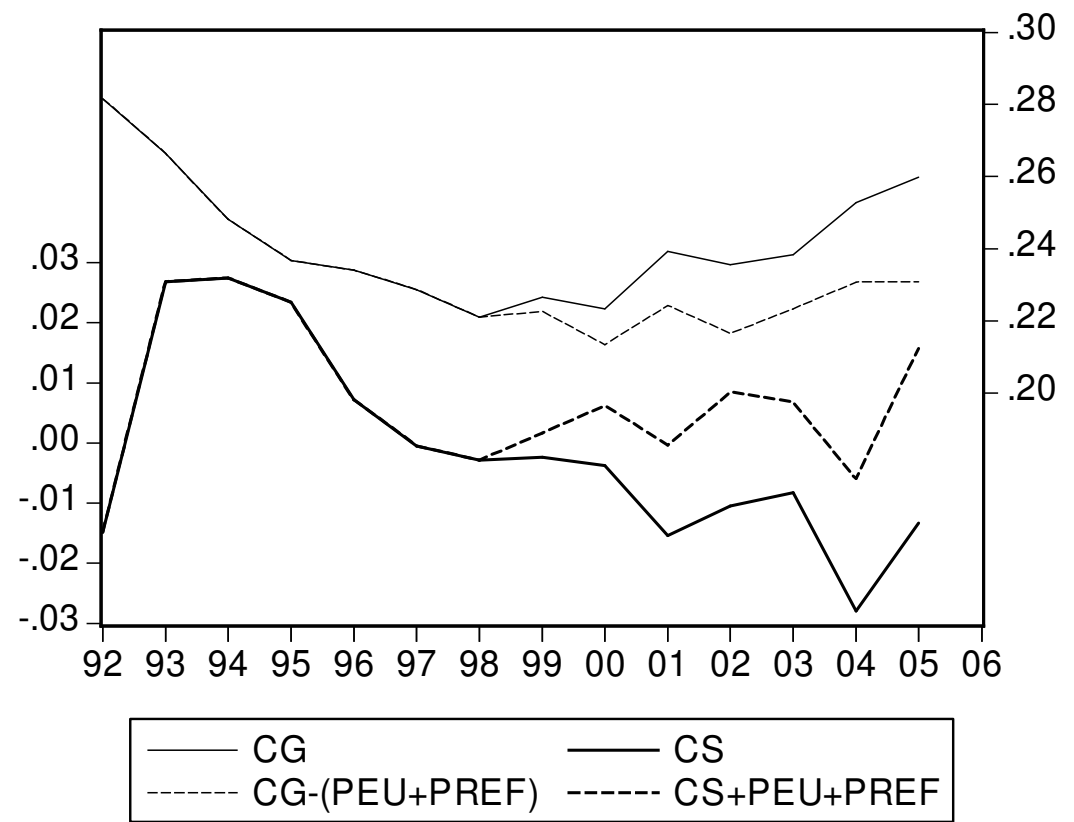
Table 1 Basic descriptive statistics of the sample

\begin{tabular}{lccccc}
\hline \hline & Debt & $\Delta$ debt & $\begin{array}{c}\text { Primary } \\
\text { surplus }\end{array}$ & Revenues & $\begin{array}{c}\text { Primary } \\
\text { expenditures }\end{array}$ \\
\hline \hline Mean & 0.551 & -0.016 & -0.001 & 0.241 & 0.242 \\
Median & 0.509 & -0.009 & -0.003 & 0.229 & 0.238 \\
Maximum & 0.861 & 0.059 & 0.027 & 0.293 & 0.282 \\
Minimum & 0.424 & -0.180 & -0.028 & 0.218 & 0.221 \\
Std. Dev. & 0.138 & 0.069 & 0.017 & 0.024 & 0.018 \\
Skewness & 1.272 & -1.044 & 0.538 & 0.950 & 0.851 \\
Kurtosis & 3.372 & 3.504 & 2.342 & 2.630 & 2.870 \\
\hline \hline
\end{tabular}

Table 2 Results of unit-root tests

\begin{tabular}{|c|c|c|c|c|c|c|}
\hline Test & & Debt & $\Delta \mathrm{Debt}$ & $\begin{array}{l}\text { Primary } \\
\text { surplus }\end{array}$ & Revenues & $\begin{array}{c}\text { Primary } \\
\text { expenditures }\end{array}$ \\
\hline \multirow{2}{*}{$\begin{array}{l}\text { Augmented } \\
\text { Dickey-Fuller }\end{array}$} & Test stat. & -1.419 & -2.436 & -1.830 & -1.247 & -1.996 \\
\hline & $\mathrm{p}$ & 0.543 & 0.152 & 0.352 & 0.622 & 0.284 \\
\hline \multirow[t]{2}{*}{ Phillips-Perron } & Test stat. & -1.451 & -2.436 & -1.924 & -1.430 & -1.506 \\
\hline & $\mathrm{p}$ & 0.528 & 0.152 & 0.313 & 0.540 & 0.501 \\
\hline $\begin{array}{l}\text { Kwiatkowski-Phillips } \\
\text {-Schmidt-Schin }{ }^{+}\end{array}$ & Test stat. & 0.347 & 0.234 & 0.408 & 0.220 & 0.229 \\
\hline Stationarity & & Inconclusive & Inconclusive & Inconclusive & Inconclusive & Inconclusive \\
\hline
\end{tabular}


Appendix C. Empirical results

Table 3 Estimation results

\begin{tabular}{lcccc}
\hline \hline Column no. & $(1)$ & $(2)$ & $(3)$ & $(4)$ \\
Dependent variable & Primary surplus & Primary surplus & Revenues & Primary expenditures \\
\hline \hline Constant & -0.051 & -0.046 & $0.165^{* * *}$ & $0.221^{* * *}$ \\
& -0.408 & -1.708 & 40.667 & 11.048 \\
Lagged debt & $0.062^{*}$ & $0.091^{*}$ & $0.132^{* * *}$ & 0.032 \\
& 1.856 & 2.088 & 20.759 & 0.901 \\
Transitory component & $1.071^{* * *}$ & $0.847^{* * *}$ & $1.284^{* * *}$ & $1.099^{* * *}$ \\
& 10.974 & 4.784 & 13.089 & 4.760 \\
PCON & & $0.062^{*}$ & & \\
& & 1.958 & & \\
Lagged debt $\times$ PCON & & $-0.145^{*}$ & & \\
& & -2.294 & & 0.756 \\
\hline \hline Adj. $\mathrm{R}^{2}$ & 0.884 & 0.911 & 0.978 & 0.790 \\
DW & 0.690 & 1.327 & 2.010 & \\
\hline \hline
\end{tabular}

Note: in italics t-statistics computed from Newey-West standard errors; asterisks indicate significance at levels: ${ }^{* * *} p<0.01,{ }^{* *} p<0.05,{ }^{*} p<0.1$

Table $4 \quad$ Results of Granger causality tests

\begin{tabular}{|c|c|c|c|c|c|}
\hline \multicolumn{2}{|c|}{$\mathrm{H}_{0}$ : No Granger causality ${ }^{++}$} & \multicolumn{2}{|c|}{ Levels } & \multicolumn{2}{|c|}{ First differences } \\
\hline from: & to: & $\mathrm{F}$ & $\mathrm{p}$-value & $\mathrm{F}$ & $\mathrm{p}$-value \\
\hline Revenues & Expenditures & 1.736 & 0.236 & 0.383 & 0.695 \\
\hline Expenditures & Revenues & 9.499 & 0.008 & 8.941 & 0.012 \\
\hline Debt & Expenditures & 0.721 & 0.515 & 0.255 & 0.782 \\
\hline Debt & Revenues & 9.422 & 0.008 & 3.962 & 0.071 \\
\hline
\end{tabular}

${ }^{++}$The null hypothesis is that there is no Granger causality between variables

Table 5 Estimation results

\begin{tabular}{|c|c|c|c|c|c|c|c|c|}
\hline $\begin{array}{l}\text { Column no. } \\
\text { Dependent } \\
\text { variable }\end{array}$ & $\begin{array}{c}(1) \\
\text { Revenues } \\
\text { Direct } \\
\text { taxes } \\
\end{array}$ & $\begin{array}{c}(2) \\
\text { Revenues } \\
\text { Indirect } \\
\text { taxes } \\
\end{array}$ & $\begin{array}{c}\text { (3) } \\
\text { Revenues } \\
\text { Others }\end{array}$ & $\begin{array}{c}\text { (4) } \\
\text { Revenues } \\
\text { Other+ } \\
\text { indirect } \\
\end{array}$ & $\begin{array}{c}\text { (5) } \\
\text { Expend. } \\
\text { Prim. } f . \\
\text { of state } \\
\end{array}$ & $\begin{array}{c}(6) \\
\text { Expend. } \\
\text { Quasi- } \\
\text { social } \\
\end{array}$ & $\begin{array}{c}(7) \\
\text { Expend. } \\
\text { Social }\end{array}$ & $\begin{array}{l}\text { (8) } \\
\text { Expend. } \\
\text { Others }\end{array}$ \\
\hline Constant & $\begin{array}{c}0.071^{* * *} \\
33.373\end{array}$ & $\begin{array}{c}0.097^{* * *} \\
35.875\end{array}$ & $\begin{array}{c}0.008 \\
1.179\end{array}$ & $\begin{array}{c}0.100^{* * *} \\
26.140\end{array}$ & $\begin{array}{c}0.032^{* * *} \\
31.112\end{array}$ & $\begin{array}{c}0.067^{* * *} \\
20.555\end{array}$ & $\begin{array}{c}0.092^{* *} \\
2.267\end{array}$ & $\begin{array}{c}0.049^{* * *} \\
4.751\end{array}$ \\
\hline Lagged debt & $\begin{array}{c}0.050^{* * *} \\
12.220\end{array}$ & $\begin{array}{c}0.033^{* * *} \\
16.339\end{array}$ & $\begin{array}{c}0.026^{* * *} \\
2.791\end{array}$ & $\begin{array}{c}0.068^{* * *} \\
11.636\end{array}$ & $\begin{array}{c}0.009^{* * *} \\
8.405\end{array}$ & $\begin{array}{c}0.013^{* *} \\
2.585\end{array}$ & $\begin{array}{c}0.024^{*} \\
2.137\end{array}$ & $\begin{array}{c}0.006 \\
0.288\end{array}$ \\
\hline Transit. c. & $\begin{array}{c}1.133^{* * *} \\
17.883\end{array}$ & $\begin{array}{c}1.139^{* * *} \\
18.680\end{array}$ & $\begin{array}{c}0.857^{* * *} \\
6.940\end{array}$ & $\begin{array}{c}1.193^{* * *} \\
8.082\end{array}$ & $\begin{array}{c}1.447^{* * *} \\
13.185\end{array}$ & $\begin{array}{c}0.976^{* * *} \\
8.965\end{array}$ & $\begin{array}{c}1.483^{* *} \\
2.810\end{array}$ & $\begin{array}{c}0.965^{* * *} \\
5.542\end{array}$ \\
\hline Adj. $\mathrm{R}^{2}$ & 0.988 & 0.948 & 0.958 & 0.946 & 0.982 & 0.868 & 0.866 & 0.719 \\
\hline DW & 1.798 & 2.108 & 1.397 & 1.798 & 1.668 & 1.415 & 1.594 & 0.796 \\
\hline
\end{tabular}


Table 6 Estimation results

\begin{tabular}{lcccccc}
\hline \hline $\begin{array}{l}\text { Column no. } \\
\text { Dependent } \\
\text { variable }\end{array}$ & $\begin{array}{c}(1) \\
\text { expenditures }\end{array}$ & $\begin{array}{c}\Delta \text { Expendit. } \\
\text { Prim. funct. } \\
\text { ef state }\end{array}$ & $\begin{array}{c}\Delta \text { Expendit. } \\
\text { Quasi-social }\end{array}$ & $\begin{array}{c}\Delta \text { Expendit. } \\
\text { Social }\end{array}$ & $\begin{array}{c}(5) \\
\Delta \text { Expendit. } \\
\text { Others }\end{array}$ & $\begin{array}{c}\Delta \text { Primary } \\
\text { expenditures }\end{array}$ \\
\hline \hline Constant & 0.026 & 0.000 & 0.008 & 0.005 & -29.142 & $0.057^{* * *}$ \\
& 0.268 & -0.081 & 0.790 & 0.372 & 0.000 & 4.253 \\
Lagged primary & -0.110 & -0.001 & -0.033 & -0.020 & -0.113 & $-0.269^{* * *}$ \\
expenditures & -0.281 & -0.080 & -0.902 & -0.354 & -1.753 & -4.613 \\
$\Delta$ Transit. c. & $0.866^{* * *}$ & $1.206^{* * *}$ & $0.854^{* * *}$ & $0.839^{* * *}$ & $0.834^{* * *}$ & $0.667^{* * *}$ \\
& 3.469 & 8.576 & 10.237 & 5.762 & 11.049 & 5.238 \\
PREF+PEU & & & & & & $0.607^{* * *}$ \\
& & & & & & 9.290 \\
\hline \hline Adj. R $\mathrm{R}^{2}$ & 0.769 & 0.784 & 0.863 & 0.496 & 0.857 & 0.911 \\
DWW & 1.415 & 1.086 & 1.666 & 1.395 & 1.593 & 2.418 \\
\hline \hline
\end{tabular}

